\title{
Interview
}

\section{In conversation with John Howells}

\section{(Part 2)}

(Part 1 appeared in the September issue of the Psychiatric Bulletin)

We should talk now about your role in the foundation of the College. I remember very well the original $R M P A$ debate at the RSM. I was sent by 'The Lancet' to report it, and was told beforehand that in general, they were not in favour of more colleges being established. But I remember particularly the opening of your speech, when you said "We can have our College now".

Yes! Well the reason for saying that was that I had been in touch with a psychiatrist called T. Moylett, a member of the Society of Clinical Psychiatrists, who had an encyclopaedic knowledge of legislation in this country. Just before that November meeting, I wrote to him, asking if there was a way by which the RMPA could become a Royal College without a new Charter and without an Act of Parliament. I got his reply the day before the meeting, saying-Yes. It was very simple, and he quoted precedents. The RSM had changed its name in 1921 to the Royal Society of Medicine by a Supplemental Charter and the Glasgow Faculty had changed its name about 1926 by the same means. So he said emphatically that all we needed was a Supplemental Charter, which was very simple legally. That was why I was able to assure people that it was possible to do this.

Later, I checked with the Privy Council. As a citizen, it is one of your privileges to be able to write to them and to the Lord Chancellor's Office on any legal question, and they have to reply to your letter. So I asked, "Am I right in thinking that it is possible to effect a change of name of a Royal body by a Supplemental Charter?" After a couple of weeks, they wrote back to say, "You are correct that this is possible". Later, just to confirm this, I wrote to the Lord Chancellor's Office and got precisely the same reply.

Why did it take so long to get the College actually established?

Bearing in mind that the whole thing was legally simple, it is a good question, why it was so difficult to execute in practice.
That takes us to the realm of the opposition to the College, which came mainly from the Royal College of Physicians, but more particularly from its Psychological Medicine Committee. Throughout their history, the RCP had been obstructive - to the general practitioners, the obstetricians, and the pathologists, and they were certainly going to obstruct us. There was a reason for this. They regarded themselves not just as a Royal College for physicians, but as covering every aspect of medicine. This, of course, had always been denied by the surgeons and the obstetricians through their own Colleges.

Within the Psychological Medicine Committee, there was a powerful group who felt that they had a privileged position within the College of Physicians and they had no desire to lose this. The guiding light there was Desmond Curran, who was violently opposed to the College's foundation. It was also opposed by Aubrey Lewis, but I think that although he was against the idea of the foundation of a College derived from the RMPA, he might have been happy to have had one separate from the RMPA. He regarded the RMPA as a second-class body and took no part in its activities himself. He was also opposed to the College because he had established the London DPM, and felt that this would be challenged by the foundation of a new body.

Yet again, within the RMPA, there was a focus of resistance in that delightful person, Alexander Walk. Now, I had the highest regard for him; in a sense, he 'was' the RMPA. He was a very able person, a true scholar, and a very loyal servant to the RMPA, but unfortunately, regarded the move towards a college as a threat to it. He could not be persuaded that a College would be the culmination of his own work. He fought against the idea right down to the last meeting of the Petitions Committee. We had a letter from the Privy Council conceding everything, and saying, "Well, we agree with you that you are ready to launch a College, so please petition immediately". But he twisted the letter around to mean the exact opposite, advising us to have no truck with the Privy Council and to cease negotiations. Happily, although he was supported by Eliot Slater, the Committee thought otherwise, and we petitioned shortly after that. 


\section{Can you describe the course of events?}

The College quest really occurred in two phases the 'open' one, when people had to persuade themselves that they needed or wanted a Royal College, and the 'closed' one, consisting of a number of steps towards the actual formation of it. I had come on to the RMPA Council at quite an early age, because I was Secretary and then Chairman of the Child Psychiatry Section, and their representative on Council. Some-one asked the Council whether we should be thinking about founding a College, and immediately he was set upon by the remainder, who insisted this wasn't an appropriate moment and in any case, we might be upsetting the Royal College of Physicians. Your Bulletin interviews with Sir Kenneth Robinson and Sir George Godber both pinpointed the opposition as being centred there. A couple of years after this first discussion, T. P. Rees raised the matter in the Psychological Medicine Committee of the BMA, but they didn't regard themselves as an appropriate body to pursue this, so they referred it to the Council of the RMPA. I'm sure that Rees intended this to happen from the very beginning. I contributed to the discussion, and when Council decided to set up a committee to explore the whole thing, they put me on it.

\section{What happened?}

Alexander Walk was the chairman, and we took evidence from a number of bodies. I was pretty naive in those days, and didn't realise that the easy way of settling any dispute is to set up a committee to explore it, but to constitute your committee in such a way that they will give you the reply that you want! Walk had in fact cleverly constituted this particular committee in such a way that it would never, ever ask for a Royal College. Well, ultimately came the moment of preparation of its report, and Walk asked for an expression of opinion. A third of the Committee wanted no action, a third wanted a Faculty within the College of Physicians, and another third wanted the Royal College. In effect, this meant a stalemate, and it was going to be difficult to write a report. So a compromise was put forward, which was that maybe the College might be a desirable aim in the future, but it wouldn't be appropriate at the moment. When it came to voting, there were 11 members in favour of the proposition, which really meant 'no action' and I opposed it. However, before the meeting, I'd had a word with T. P. Rees, because I could see what was happening, and he said "Now look here, my boy. You know you've got the right to write a minority report if you want to". So I then asked whether I could write such a report, and they had to concede that. As a result, two reports should have gone to Council, but I then went off to the States, and when I came back and looked at the minutes, I discovered that my minority report had never gone to Council.
Had it done so, had a hearing, and been turned down, I would probably have let the matter rest.

\section{What did you do next then?}

I read the Byelaws of the RMPA, though normally, people simply consulted Alexander Walk! I discovered that it was a right of a member, if he wanted, to move a motion at the Annual General Meeting, but that was the only time during the year that one could do this. That right is still maintained in the new constitution of the College. So I put down a resolution for the next AGM, and this caused great upset in the office. They were deeply offended that any member should exercise this right, and particularly that it should be on the issue of a College. I was told that this was inappropriate, that it wasn't the right time, that I would be causing offence, and that in any case, I would be disrupting the AGM. I had to insist. Then I met Monro, the Secretary, and Curran, the President, and we made a deal. If I would agree not to raise it at the AGM in July, they would defer the business part of the AGM to the quarterly meeting in November. I readily agreed to this, because I realised that the AGM was being held in a remote hospital somewhere, and there might not be a very good attendance. But the November meeting was being held in London. I think they realised later that perhaps it was a mistake to have deferred it. So came the meeting at the RSM that you mention - and reported for The Lancet.

Can you describe what happened on that occasion?

When the day came, Council had invited two other people to speak. The speaker in favour of maintaining the status quo was Leslie Cook, Superintendent of Bexley Hospital, while the speaker on having a faculty within the College of Physicians was Denis Hill. After a lively discussion, Alexander Walk, who was of course a master of procedure, moved an amendment to my motion which, being an amendment, was voted on first. Not only that, but if it was carried, then the motion would not be put. This amendment in a sense was a negative, but not a complete negative. What he was saying was "Members, leave this in the hands of your officers". Then he made a promise that there would be a postal vote, which appealed to the audience, as it seemed reasonable. So they voted and on a recount, they carried the amendment.

It looked as if there wasn't going to be a direct vote whether or not we should have a College, but happily, Curran and Walk made a miscalculation. They thought the vote meant that the people present were against a college. Curran then said "Although it's not strictly necessary under the constitution, it still would be rather nice to have a vote on the motion". I'm sure he was confident that it would be turned down, but in the event, there was a handsome majority in favour. So the whole thing ended most 
happily, because there had been a vote in favour of a college and we got a promise from the officers of a postal vote. Your account in The Lancet ended with a phrase to the effect that "This matter must now be pursued with greater urgency.

\section{What happened next?}

The next step was the postal vote, which was to take place the following January. The difficulty was that there had to be a clear question on the ballot paper, or otherwise, one might get an ambiguous answer. The wording of it was left with Walk, and his first effort at this was absolutely masterly: there were a number of questions, but it would not have been possible to get a clear answer from them as to whether or not the members wanted a college. Of course, we were dismayed by this. Three of us put our heads together - John Hutchinson, Clifford Tetlow (who recently died), and myself - to see if we could contrive one unequivocal question on the ballot paper, and if possible it should be the first one. We did ultimately gain our objective. Then, to our consternation, we heard the Council had deferred the postal ballot until May. They hoped that by then, the RMPA would be physically within the new building of the Royal College of Physicians, and that members might find it difficult to oppose our hosts. The other reason was that the College of Physicians had decided to resurrect a ploy which they had used to obstruct the obstetricians back in 1926. Then, in order to make it unnecessary to have a College of Obstetricians and Gynaecologists, they founded an examination for them. So they were now going to frame a new examination, which they thought would be suitable for psychiatry. In fact, it wouldn't have been, because the first step was to be an examination in general medicine; it was only in the final part that one could have elected to take psychiatry as a clinical subject.

\section{How did the ballot go?}

The papers went out to members in May 1964. For the Society of Clinical Psychiatrists, it seemed most important that members should reply to them, because only a short time before, the RMPA had sent out a questionnaire on the subject of remuneration and less than $10 \%$ of the membership responded. That would have been a catastrophe, because the other colleges would not have been impressed by a turnout of that sort, nor would the Privy Council. So the SCP asked me to compose a leaflet to inform every psychiatrist in the country of the importance of the occasion, and we told them "We don't mind how you vote; all we ask of you is that you vote and that you vote immediately". The next week, RMPA members received a communication from Council, giving background to the whole thing in rather pessimistic terms, and The Lancet had a leader advocating a faculty in the Royal College of Physicians, as well as a letter from the RMPA President, inviting people not to vote before considering carefully the offer being made by the Physicians. However, reacting to the SCP, most people had already voted, and as you know, there was a handsome majority in favour of the College.

\section{All this was taking time?}

Yes, but it was just the beginning of the delay. Under the constitution of the RMPA, no action could be taken in its name without it being approved at an Annual Meeting. This was set for Basingstoke in the July, and again, it was a critical moment, because it was necessary to have a handsome majority to impress the Privy Council and the other colleges. So another 'For your information' leaflet was prepared by the SCP and went to all psychiatrists, pointing out the importance of the occasion. Traditionally in the RMPA, very few people turned up to the business part of the Annual Meeting, but members of the SCP got busy all over the country, getting people together in carloads, to come to the meeting. We from Ipswich had a contingent of three cars and we arrived in the car park at Basingstoke just after nine; the meeting was to start at 9.30, but there wasn't a car in the place. However, at about 9.25, they came pouring in and in fact by 9.30 , you couldn't get in the car park! When we finally got to the hall, the place was packed. The motion was put - that the RMPA should now petition for a Royal College - and was carried by a very handsome majority. That was really the end of what you might call the 'open phase', when everybody knew what was going on and the efforts were there for everyone to see. During this time, I'd been stumping around the country talking at divisional meetings, and the President had been stumping round the country saying the opposite. Most of the contributions from the floor at these meetings were against the college, but this taught me that often, when there is an expression of opinion, people who are opposed to something will get up and express it, but those who are in favour keep to their seats.

That brings us to the 'closed phase', does it?

Yes, from now on, everything went on behind closed doors, as it were. Council had to set up a Petitions Committee to undertake the negotiations with the Privy Council, as well as another committee on the Higher examination and the Byelaws. The Petitions Committee consisted of the officers and two members, of whom I was one. Remember that from that moment until we successfully petitioned, six years went by, despite the process being so simple legally. The reasons for this were really within the RMPA itself. The only officer who had any enthusiasm for the venture was A. B. Monro, who had a great loyalty to his members; he regarded himself as their servant. However, he was 
under enormous pressure from the other officers and from what you might call the College of Physicians faction; they went so far as to offer him a Membership of that College, which in time would have gone on to a Fellowship, but he declined it. Alexander Walk, the Librarian, was violently opposed to the College proposal, as indeed were Eliot Slater, the Editor, and William Sargant, the Registrar. So in the Petitions Committee, it was very difficult to get movement forward. Ultimately, a meeting was set up between the Committee and the Secretary of the Privy Council. Monro, Slater, myself, and our solicitor represented the RMPA. But it was a frosty meeting, as Sir Geoffrey Agnew clearly wasn't interested. We talked about various matters, and he indicated there was opposition to what we were intending to do and that other colleges would have to be consulted.

The Royal College of Physicians' support was clearly crucial. How did you get that?

After a heated dialogue in Council, it was agreed that a letter should be sent to the Royal College of Physicians, inviting their support, but when it reached there, they decided to temporise. Nothing was heard from them for months. At a second heated dialogue in Council, it was agreed to write an open letter to the College of Physicians which stated that if we did not hear from them by a certain date, then we had to assume that they were not supporting the formation of a college of psychiatrists. This caused consternation within the College of Physicians, but led by Lord (Robert) Platt, who had become President, they grasped the nettle and wrote a handsome letter of support.

\section{Was there still delay?}

Yes. Matters should now have been smooth, but in the event, they were not. The easy road was to petition for a Royal Charter and then, when it was granted and the College had been founded, to undertake a leisurely revision of the Byelaws. Opponents to the College managed to sell the idea that the Byelaws and the petition should go in at the same time. As years of work were needed to negotiate with the Privy Council on the Byelaws, this led to endless delay and with each passing year there was always the prospect that members would lose interest, the issue would be forgotten, and the whole thing would peter out. You yourself were a member of the committee of the Society of Clinical Psychiatrists, and know that without the continual pressure by the SCP over the years, the matter would, indeed, have petered out and there would have been no College. However, the final agreement of the Privy Council on the Byelaws ultimately came, with the invitation to petition, and so the Royal College of Psychiatrists was founded.
$I$ understand that you stood for President of the College on one occasion.

Indeed I did, immediately after the formation of the College. There were four candidates of whom three, including myself, had been pro-College. My presidency would have made me even more unpopular than my advocacy of a College, but I would not necessarily have been wrong. My central aim would have been to change the course of psychiatry and psychiatric practice. Let me explain.

In what way?

Throughout psychiatry, there has been a widespread tendency to accept a viewpoint put forward by Szaz and others which asserts that medicine is concerned only with organic pathology. But in fact, it is concerned with illness, deviation, abnormality, in other words, all pathology - both organic and psychopathology. Indeed, they are indivisible. You can worry and develop a gastric ulcer and you can have cancer and worry about it. But neuropsychiatry and biological psychiatry are really a branch of neurology. This has been the only truly successful field of psychiatric practice, but the whole continent of emotional experience behind the unhappiness of people is neglected. Psychiatry's inability to get to grips with this field has led to frequent disparagement from general practitioners, who feel we are remote from their interests, to remoteness from our specialist colleagues, who find we give no help with their major problems, and ultimately to divorce from the public, who often feel we are impotent in helping them. Psychoanalysis has to be replaced through systematic research by realistic psychopathology. Nosology which is based upon the two big divisions of organic psychiatry and psychological psychiatry has to be completely re-written.

What else would have been in your programme?

I would also have made every effort to pull the psychiatrists away from the team concept. This crept in in a most unfortunate period of British history, that of pseudo-democracy. We failed to see that it was simply a means by which related professions crept to power on our backs. They all have laudable aspirations and should be supported, but should establish themselves in the light of their own achievements. The psychiatrist should be an individual who is highly trained in psychopathology and related organic pathology, capable of the highest standards of practice, and depends on no-one except his own judgement. I should also have been trying to relocate public funding so that psychiatry and the quest for the mental health of its people should have a far higher priority than in the present scheme of things.

How do you find retirement?

I am as busy as I ever was, but now able to choose my targets and able to proceed according to my own 
inclinations and timing. Age brings with it a new area of experience - the lives of one's grandchildren Michael, Anna, Victoria, Julian, Georgina, Henrietta, and Hedié. It is demanding, intriguing, testing of one's thinking, and invigorating. One of them has programmed his wrist computer to ring on my birthdays. Kindly, and with naive optimism, he has programmed it for the next 50 years!

I continue researching and writing. I lost my research team when I retired, and so moved into private practice; this enables me to retain some help. I am writing on psychopathology and nosology. History was always an interest since I edited World History of Psychiatry in 1975. As I mentioned earlier, for 25 years, I collected material for $A$ Reference Companion to the History of Abnormal Psychology published in 1984. It took seven years to write and three years for the publisher to produce. The two volumes are always alongside me on my desk, but their considerable cost must deter others from having them. I am now editing Concept of SchizophreniaHistorical Perspectives for the American Psychiatric Press. As Chairman of the History Section of the World Psychiatric Association, I am much involved in that organisation and with historians worldwide. I have now started a new 'Clinical Psychiatry Series' for Brunner/Mazel.

On retirement, I was given a video player, which makes it possible for me to indulge in one of my strong interests - Italian opera. I have studied Verdi in particular. He was a man of a massively strong personality, which is projected into his music. You will find him confronting a mob in the council scene in Simon Boccanegra. The love for his foster-father is found in the bass arias of his early operas, but they died with this man. His touching tribute to his 'other woman', Guiseppina, who later became his wife, penetrates the whole of La Traviata. His feelings for women always make the most melodious music of each of his operas expressed particularly in a fatherdaughter dialogue. I read Dylan Thomas and have made a particular study of the art of Salvador Dali. A new interest takes me into horticulture. I sit on the Council of the International Clematis Society, edit its journal Clematis International, and have just finished a book for Ward Lock on clematis.

\section{What advice would you give young people?}

I would suggest that they try to advance on a narrow front; you can only penetrate in depth in that way. Even so, the further you move towards truth, the more change you will advocate, and the more difficult life will become. Secondly, test your theories with daily experience; discuss them with an intelligent and creative layman. Thirdly, steel yourself to being unpopular. The insecure and the deprived in particular seek for approval and appreciation; they find unpopularity intolerable. The search of truth has to mean change; this creates insecurity, the insecure will defend themselves, and your unpopularity is an inevitable consequence. Fourthly, avoid picking up too many of the 'golden balls'. You can never reach the truth if you stoop to pick up too many committee memberships, marks of public approval, chairmanships. visiting professorships, public addresses, etc. You may end up "very distinguished', but sick with yourself for lack of real achievement.

\section{Conferences}

A joint conference between the Royal College of Psychiatrists and the College of Occupational Therapists on The Costs of Fragmentation and Psychiatry will be held on Monday, 12 November 1990 at the Royal Institute of British Architects, London W1. This will be an important occasion to consider how services for mentally ill people will be provided in the future. Speakers will include Mr Stephen Dorrel, Parliamentary Under-Secretary for Health, and Mr Louis Blom-Cooper, QC, Chairman of the Mental Health Act Commission. The programme is available from Deborah Hart at the College.
A one day conference on Working Together in Mental Health: The Multidisciplinary Team in the Next Century will take place on 23 November 1990 at St George's Hospital Medical School, London SW17 0RE. It is organised by the British Association of Social Psychiatry. Registration fee, including lunch, coffee and tea for members: £5; (for nonmembers: $£ 15$ ). Closing date: 26 October 1990. Late registration: $£ 25$. Further information: Dr Pamela Pilkington, 16 Lichfield Road, Kew, Richmond, Surrey TW9 3JR (telephone 081940 0369). 